Computer Spreadsheet Applications in Building and Surveying 
Other books by the same author

B. Cooke, Contract Planning and Contractual Procedures

B. Cooke and W. B. Jepson, Cost and Financial Control for Construction Firms 


\title{
Computer Spreadsheet Applications in Building and Surveying
}

\author{
B. Cooke and S.V. Balakrishnan
}

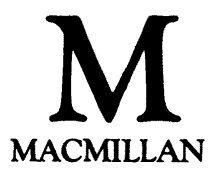


(C) B. Cooke and S. V. Balakrishnan 1985

All rights reserved. No reproduction, copy or transmission of this publication may be made without written permission.

No paragraph of this publication may be reproduced, copied or transmitted save with written permission or in accordance with the provisions of the Copyright Act 1956 (as amended).

Any person who does any unauthorised act in relation to this publication may be liable to criminal prosecution and civil claims for damages.

First published 1985

Published by

Higher and Further Education Division

MACMILLAN PUBLISHERS LTD

Houndmills, Basingstoke, Hampshire RG21 2XS

and London

Companies and representatives

throughout the world

British Library Cataloguing in Publication Data

Cooke, B.

Computer spreadsheet applications in building

and surveying.

1. Construction industry-Data processing

2. Electronic spreadsheets

I. Title II. Balakrishnan, S. V. $690^{\prime} .028^{\prime} 5425 \quad$ HD9715.A2

ISBN 978-0-333-39282-9

ISBN 978-1-349-08002-1 (eBook)

DOI 10.1007/978-1-349-08002-1 


\section{Contents}

\section{List of figures}

viii

Preface/Acknowledgements

\section{Introduction}

Spreadsheet format and hardware selected

Range of spreadsheets available commercially

Spreadsheet applications and the builder

Advantages of spreadsheets

Spreadsheet applications to building management and surveying

Objectives of the spreadsheet examples presented

Procedures to be undertaken to input a VisiCalc example from a program listing Input procedure - level one user Input procedure - level two user

Subcontractor's payment example

Procedure to operate VisiCalc and develop a spreadsheet program

Stage 1: Inserting the VisiCalc program diskette

Stage 2: Reading the VisiCalc listing

Stage 3: Inputting a listing column by column (level 1 user)

Stage 4: Inputting a listing using the replicate routine (level 2 user)

Stage 5: Saving the screen display (level 1 and level 2 users)

Stage 6: Loading a program example and entering data on the screen display

Stage 7: Printing the screen display

Contents of appendixes

2 VisiCalc applications to budgets and forecasting 13

2.1 Project cash flow 13

2.2 Company quarterly cash flow

2.3 S-curve forecast based on the DHSS formula

2.4 Cash flow analysis - labour, plant, material and subcontractor analysis ix

ix

1

1

2

.

4 VisiCalc applications to quantity surveying and estimating

3.1 Monthly expenditure ledger

3.2 Present value assessment - percentage

3.3 Client's ledger account

3.4 Monthly cost/value reports

4.1 Subcontractor's payment 48

4.2 Monthly valuation statement 52

4.3 Budget estimating program - brickwork trade

4.4 Development budget - feasibility assessment (residual value method)

4.5 Life cycle costing - economics of development assessment

4.5A Present value of the initial, running and replacement costs

4.5B Annual equivalent method

4.6 Painting material estimate

5 VisiCalc applications to plane surveying

5.1A Reduced level booking - height of collimation

5.1B Reduced level booking - rise and fall method

5.2 Closed traverse calculation

5.3 Circular curve - setting out using deflection angles

5.4 Circular curve - setting out by offsets

from the main chord 96

5.5 Stadia tacheometry - radial method 106

5.6 Open traverse 
vi Contents

6 Using the program applications on the BBC Model B microcomputer

Appendix 1: VisiCalc and UltraCalc Spreadsheet commands

Appendix II: Details for obtaining VisiCalc

Appendix III: Obtaining the program discs for the applications in the text
Disk details - ordering instructions:

VisiCalc disk ref V100, V101, V102

Disk details - ordering instructions:

$B B C$ disc ref $B B C 100, B B C 101$,

BBC102

125

Appendix IV: Microcomputers suitable for

VisiCalc applications

126

Appendix V: VisiCalc reading references 


\section{List of figures}

\section{Introduction}

1.1 Subcontractor's payment - blank master 4

1.2 Subcontractor's payment - cell listings A to $\mathrm{H} \quad 5$

1.3 Subcontractor's payment - cell listings I to N $\quad 6$

1.4 Subcontractor's payment - calculated data $r$

1.5 VisiCalc spreadsheet format $\quad 8$

$\begin{array}{ll}1.6 & \text { Overall screen format after inputting cell location A11 }\end{array}$

\section{Project cash flow}

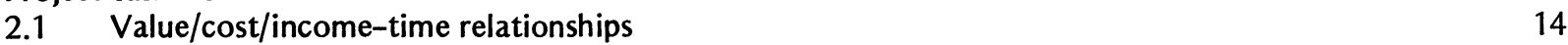

2.2 Project cash flow - blank master 15

2.3 Project cash flow - calculated data $r$

$\begin{array}{ll}2.4 & \text { Cash flow diagram } \\ \end{array}$

Company quarterly cash flow

2.5 Company cash flow - blank master $\quad 18$

\begin{tabular}{ll}
2.6 & Company cash flow - calculated data \\
\hline
\end{tabular}

S-curve forecast based on the DHSS formula

2.7 Summarised information on four contracts being undertaken simultaneously 24

2.8A Contract data file - blank master 25

2.8B Cash flow aggregating/contract budget - blank master 26

2.9 Contract data file - calculated data 26

2.10A Contract budget, contract 1 - calculated data $r$

2.10B Contract budget, contract 2 - calculated data 28

Cash flow analysis - labour, plant, material and subcontractor analysis

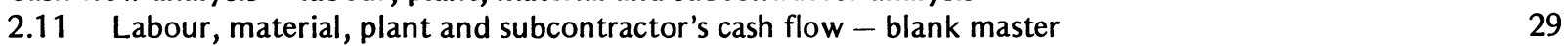

2.12 Labour, material, plant and subcontractor's cash flow - calculated data 30

Monthly expenditure ledger

3.1 Monthly expenditure ledger - blank master $\quad 32$

3.2A Monthly expenditure ledger - calculated data 33

3.2B Yearly summary master $\quad 33$

Present value assessment - percentage yield

3.3 Principles of the present value assessment 36

$\begin{array}{lll}3.4 & \text { Present value assessment - blank master } & 37\end{array}$

3.5 Present value assessment, plant item A - calculated data, choice $1 \quad 38$

3.6 Present value assessment, plant item A - calculated data, choice $2 \quad 38$

$\begin{array}{lll}3.7 & \text { Present value assessment, plant item B - calculated data } & 39\end{array}$

Client's ledger account

3.8 Client's ledger account - blank master 42

3.9 Client's ledger account - calculated data 43 


\section{viii List of Figures}

\section{Monthly cost/value report}

$\begin{array}{lll}3.10 \text { Cost/value report - blank master } & 44\end{array}$

3.11 Cost/value report, all contracts - calculated data 445

3.12 Cost/value report, individual projects - blank master 445

\section{Subcontractor's payment}

$\begin{array}{llr}4.1 & \text { Subcontractor's payment - blank master } & 49\end{array}$

\begin{tabular}{ll}
4.2 & Subcontractor's payment - calculated data \\
\hline
\end{tabular}

Monthly valuation statement

\begin{tabular}{ll}
4.3 & Valuation statement - blank master \\
\hline
\end{tabular}

4.4 Valuation statement - calculated data $\quad 53$

\section{Budget estimating program}

$\begin{array}{ll}4.5 & \text { Estimating program, brickwork - blank master } 1\end{array}$

4.6 Estimating program, brickwork - blank master $2 \quad 56$

$\begin{array}{lll}4.7 & \text { Factory building - pictorial view } & 57\end{array}$

$\begin{array}{lll}4.8 & \text { Estimating program, brickwork - calculated data } 1 & 58\end{array}$

$\begin{array}{llr}4.9 & \text { Estimating program, brickwork - calculated data } 2 & 59\end{array}$

Development budget - feasibility assessment (residual value method)

$\begin{array}{ll}4.10 & \text { Development budget - blank master }\end{array}$

4.11 Development budget - calculated data $r 62$

Present value of the initial, running and replacement costs

4.12 Net present value of initial cost, running cost and replacement costs 65

4.13A Cost in use, present value assessment - blank master $\quad 67$

$\begin{array}{rr}4.13 \mathrm{~B} \text { Cost in use, present value assessment - calculated data } & 68\end{array}$

Annual equivalent method

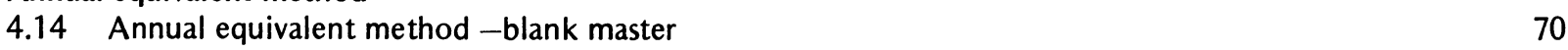

$\begin{array}{ll}4.15 & \text { Annual equivalent method - calculated data } \\ \end{array}$

Painting material estimate

$\begin{array}{ll}\text { 4.16 Painting material estimate - blank master } & 74\end{array}$

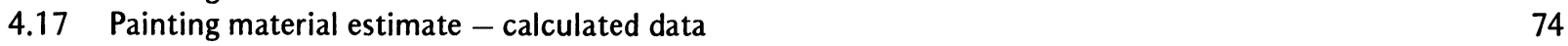

Reduced level booking - height of collimation

5.1 Reduced level booking, collimation method (2 decimal places) - blank master 77

5.2 Reduced level booking, collimation method (2 decimal places) - calculated data, worked example 178

5.3 Reduced level booking, collimation method (3 decimal places) - blank master 81

5.4 Reduced level booking, collimation method (3 decimal places) - calculated data, worked example 281

Reduced level booking - rise and fall method

5.5 Reduced level booking, rise and fall method - blank master $\quad 85$

5.6 Reduced level booking, rise and fall method - calculated data, worked example $3 \quad 85$

5.7 Reduced level booking, rise and fall method - calculated data, worked example $4 \quad 86$

\section{Closed traverse calculation}

5.8A Layout of a closed traverse $\quad 90$

$\begin{array}{ll}\text { 5.8B Input data for the traverse } & 91\end{array}$

5.9 Closed traverse - blank master $\quad 92$

5.10 Closed traverse - continuation of blank master 92

5.11 Closed traverse - calculated data 93

5.12 Closed traverse - continuation of calculated data 93 
Circular curve - setting out using deflection angles

$\begin{array}{lr}5.13 \text { General properties of a circular curve } & 94\end{array}$

5.14 Principles of setting out the circular curve using deflection angles 95

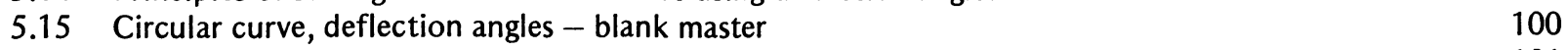

$\begin{array}{ll}5.16 & \text { Circular curve, deflection angles - calculated data } \\ \end{array}$

Circular curve - setting out by offsets from the main chord

$\begin{array}{ll}5.17 & \text { Principles of setting out the circular curve by offsets from the main chord } \\ 5.18 & 102\end{array}$

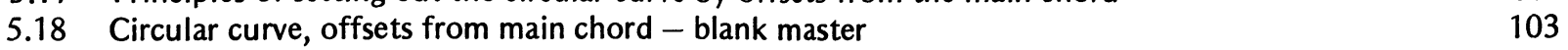

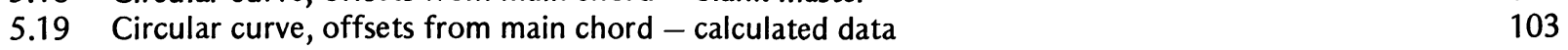

$\begin{array}{ll}5.20 & \text { Layout of the curve, showing offset positions and lengths } \\ \end{array}$

Stadia tacheometry - radial method

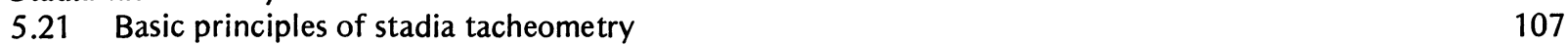

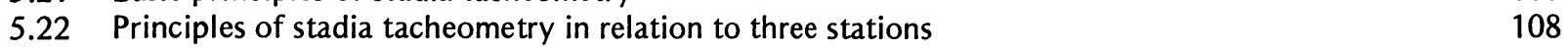

$\begin{array}{lr}5.23 & \text { Stadia tacheometry - blank master } \\ 5.24 & 109\end{array}$

$\begin{array}{lr}5.24 & 109\end{array}$

\section{Open traverse}

$\begin{array}{ll}5.25 & \text { Layout of an open traverse } \\ 5.26 & 115\end{array}$

\begin{tabular}{ll}
5.26 & Layout of an open traverse, with input data \\
\hline
\end{tabular}

\begin{tabular}{ll}
5.27 & Open traverse - blank master \\
\hline
\end{tabular}

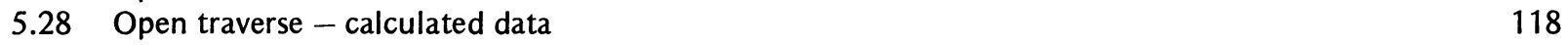




\section{Preface}

The book is intended to encourage both building managers and students to develop spreadsheet applications as an aid in the utilisation of microcomputers in building.

A range of applications are outlined which relate to office and accounting routines through to cash flow predictions. A number of procedures are indicated relating to the standardisation of monthly valuations and payments to subcontractors. Further applications relate to site surveying procedures including the reduction of levels, traverse calculations and the presentation of data for setting out circular curves. The spreadsheet format can be readily adapted to estimating procedures as well as to preparing development budgets at the contract feasibility stage.

Within each application area, the basic principles are first outlined together with the development of a blank master screen display which lays out the various headings for the spreadsheet. A worked example and full cell listings are included where possible. Full instructions are outlined to enable the user to develop his own screen display from the listings. A disk copy is also available (see appendix III).

The spreadsheet applications are based on using the VisiCalc ${ }^{\circledR}$ program diskette (VisiCalc is a registered trademark of VisiCorp Inc., San Jose, California, U.S.A.). This is suitable for use on the Apple II and III, Atari 800, Commodore PET 2001 and 8032, DEC, Hewlett-Packard 125, IBM Personal Computer and TRS 80 Model 1.

The program listings may be directly input on to the UltraCalc spreadsheet available for the BBC Model B computer, developed by BBC Software. Instructions are included for adapting the program listings to the BBC Model B computer.

\section{PROGRAM DISK AVAILABILITY}

The spreadsheet programs contained in chapters 2 to 5 are available on a $5 \frac{1}{4}$ inch disk for the Apple II + C, $48 \mathrm{~K}$ microcomputer and the BBC Model B microcomputer. Refer to appendix III for details of how to obtain the disk. The user must obtain the appropriate VisiCalc diskette or UltraCalc ROM in order to run the program disk available.

\section{Acknowledgements}

The authors wish to thank the support given by the Chartered Institute of Building during the undertaking of a CIOB Silver Jubilee Scholarship supervised by Dr M. Barnes. Assistance with the production of computer printout displays was afforded by Mr M. Anderton at Gloucester College of Arts and Technology.

The work undertaken in editing the script was ably carried out by Mr W. Perry, without whose expertise and advice we would not have been able to produce a readable text.

Finally we hope that building and surveying students and lecturers will gain from our experiences in developing the spreadsheet applications outlined. 